\title{
ROLE OF FAMILY IN IMPLEMENTATION OF DIABETES EXERCISE IN TYPE 2 DIABETES MELITUS PATIENTS
}

\author{
Lono Wijayanti ${ }^{1}$ \\ ${ }^{1}$ Faculty of Nursing and Midwifery, Nahdlatul Ulama University, Surabaya, East Java \\ *Correspondence: \\ Lono Wijayanti \\ Email: lono@unusa.ac.id
}

\begin{abstract}
Background: Diabetes mellitus is a group of metabolic diseases characterized by an increase in blood glucose levels (hyperglycemia), which occurs due to abnormal insulin secretion, insulin activity and both (Brunner \& Suddarth, 2014). The role of the family is needed for diabetics related to well-being and health where the family environment is a place for individuals to learn for life (Friedman, 2010). The role of the family is the most powerful indicator in giving a positive impact on the implementation of diabetes exercise which acts as a glicemic control which is controlling and regulating blood sugar levels.

Objectives: The aim of the study was to describe the role of families in implementing diabetes exercise in type 2 Diabetes Mellitus (DM) patients at Gayungan Health Center, Dukuh Menanggal, Surabaya.

Method: The design of this study used descriptive research. The population is all families who have family members with diabetes mellitus cases with a large sample of 40 people. Sampling using the total sampling technique. The variables studied were the role of family in implementing diabetes exercise. Data collection is done by distributing questionnaires.

Results: The results of the study showed that of the 40 respondents in the Gayungan Community Health Center working area in Dukuh Menanggal dated $40 \%$ the role of good family, $32.5 \%$ was sufficient, 27.5 was lacking in supporting the implementation of diabetes exercise

Conclusion: The family role of almost half is in the good category. The family should play an active role in the management of diabetes exercises in family members who suffer from diabetes mellitus so that blood glucose levels can be controlled properly.
\end{abstract}

Key words: The role of the family, diabetes exercise, diabetes mellitus.

\section{INTRODUCTION}

Diabetes mellitus is a group of metabolic diseases characterized by hyperglycemia due to impaired insulin secretion, insulin action, or both. Chronic hyperglycemia from diabetes is associated with long-term damage, impaired function and failure of various organs, especially the eyes, kidneys, nerves, heart and blood vessels (ADA, 2012).

In the management of nonpharmacological Diabetes Mellitus can be done by setting a food diet and physical exercise. The type of physical exercise recommended for people with diabetes mellitus is diabetes exercise, but most people, especially those with diabetes mellitus, are lazy to do diabetes exercises, because the distance between the
Puskesmas and their homes is far enough so they have to walk as far as $\pm 1 \mathrm{~km}$ to the Puskesmas because no one was delivering other than it was too old to do exercises.

In patients with type 2 diabetes, diabetes exercise has a major role in regulating blood sugar levels. When doing exercises, the state of membrane permeability to glucose increases in the muscles that contract so that insulin resistance decreases. Exercises diabetes is low impact and rhythmic aerobic exercise, the movements are fun and not boring, and can be followed by all age groups so that attracts the enthusiasm of the group in diabetes clubs. This diabetes exercise has the benefit of burning the body's calories so that blood glucose can be 
used for energy and can reduce blood sugar levels (Widianti et al., 2010).

Based on data from the World Health Organization, the number of people with diabetes mellitus in the world from year to year shows an increase. The majority are at the age of 40-60 years and as many as $80 \%$ of people with diabetes mellitus in the world come from developing countries, one of which is Indonesia (WHO, 2013). Indonesia is ranked 7 th out of all countries in the world, based on International Diabetes Federation data, the number of people with type 2 diabetes mellitus in Indonesia was 9.1 million in 2014, up to 10 million in 2015 (IDF, 2015). According to Riskesda data a number of diabetics in East Java in 2007 were 275,462 increasing to 605,974 sufferers in 2013 (Indonesian Ministry of Health, 2014). Based on Surabaya Health Office data in 2013, cases of DM in Surabaya City in 2010 were 21,729 Sufferers, and increased again to 26,613 in 2013 (Surabaya Health Profile, 2014).

Based on DM classification, the number of patients with type $2 \mathrm{DM}$ in 2008 is estimated to reach 12.3 million people and will increase to 19.4 million in 2010. According to Lanywati (2011), exercises is ranked third after drug and diet therapy, gymnastic success of almost $23 \%$, from $45 \%$ drug therapy and $32 \%$ diet therapy. Nevertheless, research conducted by C. Fajar Sri Wahyuniati, et al. In 2004, it was proven that regular diabetes exercise can be used to reduce blood sugar levels by $44.20 \mathrm{mg} / \mathrm{dl}$. Based on data at Gayungan Health Center, Surabaya, there were 200 participants participating in diabetes exercise, 100 of whom were DM patients. Of the $100 \mathrm{DM}$ patients, 60 people $(60 \%)$ had type 2 diabetes mellitus and 40 people $(40 \%)$ had type 1 diabetes mellitus. However, based on data from diabetes exercises participants, the number of gymnastic participants decreased every month.

Complications in patients with diabetes mellitus include acute complications and chronic complications. Acute complications include diabetic ketoacidosis and nonketoacidosis coma, while chronic complications include microvascular complications where the hair vessels are stiff so that the body's organs lack blood supply (Mahendra, 2008).

Handling efforts from the above problems, by encouraging diabetics to do diabetes exercise because diabetes exercise has a major role in regulating blood sugar levels. Diabetes mellitus requires proper treatment so that complications do not occur, because diabetes mellitus cannot be cured can only be controlled so that monitoring of blood glucose levels is needed.

Family has an important role in the care of family members who suffer from diabetes mellitus. The role of the family is the most powerful factor in making a positive impact on self-care in diabetics (Neff in Hensarling, 2009)

Given the treatment and treatment of DM requires a long time of course can cause boredom and boredom in patients with DM. Therefore, the participation of family members in guiding medication, diet, diabetes exercise is an active participation form for the successful management of diabetes mellitus. Furthermore, guidance for other family members to work together to solve the problem of diabetes mellitus can only be done if there is a close relationship between health workers and the patients and their families (Rifki, 2009).

The low level of family participation will have an impact on the implementation of management of type 2 diabetes mellitus. Therefore, researchers are interested in knowing the description of the role of the family in exercising diabetes in patients with type 2 mellitus.

\section{METHODS}

\section{Study Design}

The research design used is descriptive, which is a method of research carried out with the aim of describing the role of the family in the implementation of diabetes exercise in people with diabetes mellitus in the Gayungan Community Health Center, Dukuh Menanggal, Surabaya.

\section{Setting}

This research was conducted in the Gayungan Community Health Center, Dukuh Menanggal, Surabaya.

\section{Research Subject}

The population in this study were all families (wives, husbands / children) who had family members with cases of Diabetes Mellitus in the Gayungan Health Center for 40 people. The technique sampling was 
used total sampling. The number of samples was 40 people.

\section{Instrument}

The variables studied were the role of the family in implementing diabetes exercise. Data collection is done using a questionnaire.

\section{Data Analysis}

The results of this study were analyzed using the description tabulation of the role of the family in implementing diabetes exercise.

\section{RESULTS}

Characteristics of Respondents by Educational Level

Table 1. Characteristics of Respondents by Educational Level in the Gayungan Community Health Center, Dukuh Menanggal, Surabaya $(n=40)$.

\begin{tabular}{llcc}
\hline No & Education & n & \% \\
\hline 1 & Basic & 27 & 67.5 \\
2 & Intermediate & 12 & 30.0 \\
3 & University & 1 & 2.5 \\
\hline \multicolumn{2}{l}{ Total } & 40 & 100 \\
Sources: & Primary Data & &
\end{tabular}

Based on Table 1 shows that the characteristics of respondents by educational level was basic educational level, as many as 27 respondents $(67.5 \%)$.

Characteristics of Respondents by Occupational

Table 2. Characteristics of Respondents by Occupational in the Gayungan Community Health Center, Dukuh Menanggal, Surabaya $(n=40)$.

\begin{tabular}{llcc}
\hline No & Occupational & n & \% \\
\hline 1 & Civil servants & 0 & 0 \\
2 & Private & 31 & 77.5 \\
3 & Does not work & 9 & 22.5 \\
\hline \multicolumn{2}{l}{ Total } & 40 & 100 \\
Sources: Primary Data
\end{tabular}

Based on Table 2, it was found that most half of the respondents had the occupational as private job as many as 31 respondents $(77.5 \%)$.
Characteristics Relationship of Mellitus Patients with Respondents

Table 3. Characteristics Relationship of Diabetes Mellitus Patients with Respondents in the Gayungan Community Health Center, Dukuh Menanggal, Surabaya $(n=40)$.

\begin{tabular}{llcc}
\hline No & $\begin{array}{l}\text { Relations with } \\
\text { Respondents }\end{array}$ & n & \% \\
\hline 1 & Child & 21 & 52.5 \\
2 & Mother & 9 & 22.5 \\
3 & Husband/wife & 7 & 17.5 \\
4 & Brother/Sister & 3 & 7.5 \\
\hline \multicolumn{2}{l}{ Total } & 40 & 100 \\
Sources: Primary Data & &
\end{tabular}

Based on Table 3, it was found that the characteristics relationship of diabetes mellitus patients with respondents was child, as many as 21 respondents $(52.5 \%)$.

Characteristics of Respondents by The Role of Families in Exercises Implementation

Table 4. Characteristics of Respondents by The Role of Families in Exercises Implementation in the Gayungan Community Health Center, Dukuh Menanggal, Surabaya ( $\mathrm{n}=$ 40).

\begin{tabular}{llll}
\hline No & $\begin{array}{c}\text { The Role of the } \\
\text { Families in } \\
\text { Exercises } \\
\text { Implementation }\end{array}$ & n & \% \\
\hline $1 \quad$ Good & 16 & 40.0 \\
2 & Enough & 13 & 32.5 \\
3 & Less & 11 & 27.5 \\
\hline Total & 40 & 100 \\
\hline Sources: Primary Data
\end{tabular}

Based on the Table 4, it was found that almost half of good role's families in exercise implementation were 16 respondents $(40.0 \%)$.

\section{DISCUSSION}

Based on the results of the study showed that of the 40 respondents in the Gayungan Community Health Center Dukuh Menanggal Surabaya working area, almost half of the respondents' family roles were good in implementing diabetes exercise in DM patients as much as $40 \%$. 
This is possible because family relationships with respondents with diabetes mellitus have a main family relationship based on table 3 , namely children (52.5\%), mothers $(22.5 \%)$, husband / wife $(17.5 \%)$ the rest are brothers as much as $(7.5 \%)$ where the emotional attachment between family and patients is tighter because living together in one house and paying more attention to supervising family members who suffer from diabetes mellitus.

This is in accordance with the opinion of Friedman (2010), that the family is a collection of two or more people who live together with the rules and emotional attachments and individuals have their respective roles which are part of the family.

Mills (2008) said that emotional attachment is a component of family support for patients, where emotional support creates a sense of security for families who accept and families who play a role in this support, sources of support and this role is obtained from life partners, family members who have a harmonious relationship.

Based on table 2 shows that of the 40 respondents most of them had private jobs, which were $31(77.5 \%)$. In this case the private work has an influence on the role in the implementation of diabetes exercise, where private workers are more preoccupied with their work so that they are less in giving attention to their families and middle to lower socio-economic factors that are closely related to the ability of families and applying the infrastructure needed, so that if this socioeconomic condition is not good, it will have an impact on the infrastructure for providing free time in the implementation of diabetes exercise. According to Nursalam (2008) that work is generally an activity that takes time to support life and family.

While based on table 4 , the less influential families are almost half, namely $27.5 \%$. This is related to the family education level of Diabetes Mellitus patients who are still low, most of them have basic education (SD - SMP) as many as 27 people $(67.5 \%)$. Where the patient's family still considers Diabetes Mellitus is a disease that cannot be cured so the family is reluctant to motivate patients to take part in diabetes exercise.

In patients with diabetes mellitus who want to carry out diabetes exercise generally have a family that plays a good role where the family always supports the routine in taking part in diabetes exercise, this is because the family is one of the supporting factors in the implementation of diabetes exercise in addition to understanding Instruction, level of education, beliefs, attitudes and personality, According to Friedman (2010) the role of the family is a set of behaviors that are expected to be socially related to the functions of individuals in certain situations in order to meet their own expectations or expectations of people others.

The role of a good family can influence the implementation of diabetes exercise because the role of the family is one of the efforts to adhere to implementing diabetes exercise. Therefore, efforts to increase family participation are needed in improving the quality of life for people with diabetes, namely the participation of the family which is the smallest unit in the community. Families can find out about the correct information about diabetes exercise so that in families there is no leprophobia and families can provide encouragement to treatment, provide a safe and healthy environment for people with diabetes mellitus.

This is in accordance with the opinion of Carpenito (2013), that one of the factors that influence compliance is the role of the family who can influence in determining individual health beliefs and values because the family as a supporter and decision maker regarding the care of family members who sick. One family function in general is the function of care / health care (the health care function) to maintain the health condition of family members in order to continue to have high productivity (Friedman, 2014).

\section{CONCLUSION}

Based on the results of the study there are several things that can be concluded, among others:

1. Based on the results of the study it can be concluded that the families of diabetic mellitus as respondents in the Gayungan Community Health Center, Dukuh Menanggal Surabaya mostly have basic education, have private jobs, have very close relations with sufferers namely as children, and almost half play a role in supporting diabetes exercise. 
2. The family is expected to play a more active role in the management of medication, diet and diabetes exercise in family members who suffer from diabetes mellitus so that blood glucose levels can be controlled properly.

\section{SUGGESTION}

The family should play an active role in the management of diabetes exercises in family members who suffer from diabetes mellitus so that blood glucose levels can be controlled properly.

\section{REFERENCES}

Agus, S. (2007). Pengaruh Latihan Fisik; Senam Aerobik Terhadap PenurunanKadar Gula Darah Pada Penderita DM Tipe 2 di Wilayah Puskesmas Bukateja Purbalingga. Semarang: PSIK FK UNDIP.

American Diabetes Association (ADA). 2012. Diagnosis and Classification of Diabetes Mellitus. Diabetes Care Journal, 35(1), 64-71.

Brunner \& Suddarth. 2014. Keperawatan Medikal Bedah. Edisi 8. Volume 2. Jakarta: EGC.

Carpenito, L. J. (2013). Diagnosa Keperawatan: Aplikasi pada Praktek Klinik (Terjemahan). Edisi 6. Jakarta: EGC.

Friedman, MM.Bowden, VR,\& Jones, EG. (2010). Buku Ajar Keperawatan Keluarga Teori dan Praktek. Alih bahasa, Akhir Yani S.Hamid dkk; Ed.5 Jakarta: EGC.

Friedman. (2014). Buku Ajar Keperawatan Keluarga Riset, Teori, \& Praktik. Jakarta: ECG.

Guyton \& Hall. (2012). Buku Ajar Fisiologi Kedokteran. Edisi 11. Jakarta: EGC.

Hensarling, J. (2009). Development and Psychometric Testing of Hensarling's Diabetes Family Support Scale. a disertation Degree of Doctor of Philosophy in the Graduate Shool of Texa's Women's University. Retrieved from www.proquest.com on January 10, 2013.
Kariadi KS, Hartini. (2009). Diabetes? Siapa takut!!. Bandung: Qanita.

Lanywati, Endang. (2011). Diabetes Mellitus Penyakit Kencing Manis. Yogyakarta: Arcan.

Mahendra, B. (2008). Care yourself, Diabetes Mellitus. Jakarta: Penebar Plus.

Maulana, Mirza. (2009). Mengenal Diabetes Mellitus: Panduan Praktis Menangani Penyakit Kencing Manis. Jogjakarta: Katahati.

Mills. L. (2008). Diabetes: Self-Esteem and Family Suport. Retrieved from http://www.americanchronicle.com on May 7, 2013.

Misnadiarly. (2006). Diabetes Mellitus Mengenali Gejala Menanggulangi Mencegah Komplikasi. Jakarta: Pustaka Popular Obor.

Mistra (2010). Tiga Jurus Melawan Diabetes Melitus. Jakarta: Graha Medika.

Notoatmodjo, Soekidjo. (2005). Metodologi Penelitian Kesehatan. Jakarta: Rhineka Cipta.

Nursalam. (2008). Proses dan dokumentasi keperawatan konsep dan praktik. Edisi 2. Jakarta: Salemba Medika.

Rifki, N.N. (2009). Penatalaksanaan Diabetes dengan Pendekatan Keluarga, dalam Sidartawan, S., Pradana,S \& Imam, S. Penatalaksanaan Diabetes Terpadu. Jakarta: Balai Penerbit FKUI.

Riset Kesehatan Dasar. (2013). DM di Indonesia. Jakarta. Retrieved from http://www.depkes.go.id on May 8, 2018.

Widianti, Anggriyani Tri, \& Atikah Proverawati. 2010. Senam Kesehatan. Yogyakarta: Nuha Medika.

World Health Organization. (2013). Prevalensi Diabetes Melitus di Indonesia. Retrieved from http://www.depkes.go.id. On January 3, 2014. 
Cite This Article As: Wijayanti, L. Role of Family in Implementation of Diabetes Exercise in Type 2 Diabetes Melitus Patients. Nurse and Health: Jurnal Keperawatan 2018; 7(2): 152-157. 